\title{
KAJIAN PEMENUHAN KEWAJIBAN PERPAJAKAN WAJIB PAJAK MELALUI E- SYSTEM (STUDI DI KANTOR PELAYANAN PAJAK PRATAMA PEMATANG SIANTAR)
}

\author{
Ehiskia Pardede \\ Politeknik Keuangan Negara STAN \\ Irwan Aribowo \\ Politeknik Keuangan Negara STAN
}

Email: 2301180035.ehiskiapardede@gmail.com; irwan aribowo@pknstan.ac.id

\section{INFORMASI ARTIKEL}

Diterima Pertama

[26082021]

Dinyatakan Diterima

[19112021]

KATA KUNCI:

E-system, e-registration, e-billing, e-filling, e-form, $e$-SPT

KLASIFIKASI JEL:

$\mathrm{H} 2$

\section{ABSTRAK}

The e-tax system is an electronic tax system for online counting, depositing, and reporting by taxpayers. This electronic system is implemented to reduce taxpayers' time in carrying out their tax obligations. This research was conducted to review the use of e-tax system services in the form of e-registration, e-billing, e-filling, e-form, and e-SPT; find out the obstacles experienced by taxpayers and tax officers in the use of the e-tax system; and find out efforts to optimize the use of the e-tax system at KPP Pratama Pematang Siantar. The method was qualitative research. Methods of collecting data were interviews, document collection, and literature study. The result of this research indicates that there is an increase in the use of e-registration and e-billing, but due to miscommunication between tax employees and taxpayers, there is a decrease in online reporting of the 2020 Annual SPT; tax employees and taxpayers have obstacles both from internal and external sides so that the important thing and a shared task is to encourage tax morale to increase voluntary compliance of taxpayers themselves

E-system perpajakan merupakan sistem elektronik untuk penghitungan, penyetoran dan pelaporan pajak secara online oleh wajib pajak. Sistem elektronik ini diterapkan untuk mengurang waktu wajib pajak dalam menunaikan kewajiban perpajakannya. Penelitian ini dilakukan untuk meninjau penggunaan layanan $e$ system perpajakan berupa e-registration, e-billing, e-filling, e-form, dan e-SPT; mengetahui hambatan-hambatan yang dialami wajib pajak dan pegawai pajak dalam penggunaan e-system perpajakan; dan mengetahui upaya yang dapat dilakukan untuk optimalisasi penggunaan e-system perpajakan di KPP Pratama Pematang Siantar. Metode penelitian yang digunakan adalah kualitatif. Metode pengumpulan data dilakukan dengan wawancara, pengumpulan dokumen, dan studi pustaka. Hasil penelitian ini menunjukkan bahwa terjadi peningkatan penggunaan e-registration dan e-billing, namun karena adanya miskomunikasi antara pegawai dengan wajib pajak menyebabkan terjadinya penurunan pelaporan SPT Tahunan tahun 2020 secara online; pegawai dan wajib pajak memiliki hambatan baik dari sisi internal maupun eksternal sehingga hal penting dan menjadi tugas bersama adalah mendorong moral pajak guna meningkatkan kepatuhan sukarela wajib pajak itu sendiri. 


\section{PENDAHULUAN}

Ketergantungan manusia terhadap teknologi menuntut setiap sektor melakukan inovasi untuk dapat beradaptasi di tengah kemajuan teknologi, begitu juga halnya dengan perpajakan di Indonesia. Darussalam et al. (2019, dikutip dalam Blume \& Bott, 2015) menyatakan, pemanfaatan teknologi dilakukan untuk menciptakan proses administrasi perpajakan yang sederhana dan pelayanan yang lebih baik terhadap wajib pajak. World Bank mencatat bahwa penggunaan teknologi dalam sistem perpajakan memengaruhi secara signifikan waktu yang dihabiskan wajib pajak untuk menunaikan kewajiban perpajakannya. Pengembangan sistem elektronik pajak dapat mengikis waktu guna memenuhi kewajiban perpajakan. (Tobing, 2019)

Pemanfaatan teknologi menjadi hal yang sangat dibutuhkan dan perlu ditingkatkan. Ditambah lagi pada tahun 2020 Indonesia mengalami krisis yang disebabkan pandemi corona virus desease-19 (covid-19). Masalah kesehatan pernafasan yang disebabkan covid-19 menuntut setiap orang mengurangi interaksi secara langsung dengan orang lain, jaga jarak dan tatap muka virtual menjadi prioritas. Meskipun demikian keadaan ini merupakan suatu tantangan bagi setiap kantor pelayanan pajak, perjalanan awal menuju digital memerlukan penyesuaian serta usaha yang lebih dari pegawai pajak dan wajib pajak. Jawas et al. (2017) berpendapat, penerapan sistem online yang telah disediakan Direktorat Jenderal Pajak (DJP) juga identik dengan pengguna teknologi tersebut. Pengguna dalam hal ini adalah wajib pajak, sehingga tingkat penguasaan teknologi wajib pajak juga mempengaruhi pelaksanaan sistem online itu sendiri.

Berdasarkan laporan survei internet Asosiasi Penyelenggara Jasa Internet Indonesia (APJII) Irawan et al. (2020), persentase penetrasi pengguna internet 2019-2020 (Q2) mengalami peningkatan 8,9\% dari tahun 2018 yakni sebesar 196,71 juta jiwa dari total populasi 266,91 juta jiwa. Peningkatan pengguna internet terjadi pada tahun 2020. Hal ini dapat terlihat juga dari penggunaan e-system perpajakan dalam pelaporan SPT tahunan secara elektronik. Untuk pelaporan SPT tahunan 2020 secara nasional, sebanyak 11.892.462 SPT atau sebesar 95,3\% dari total SPT dilaporkan secara elektronik melalui e-Filing, e-Form, dan e-SPT. Jumlah tersebut naik $13,3 \%$ jika dibandingkan dengan jumlah pelaporan SPT tahun 2019. (Pajak, 2021)

Peningkatan tersebut juga berlaku pada Kantor Wilayah Direktorat Jenderal Pajak (Kanwil DJP) Sumatera Utara II. Berdasarkan siaran Pers DJP (2021), minat masyarakat dalam menggunakan SPT elektronik secara daring di Kanwil DJP Sumatera Utara II semakin tinggi. Hal tersebut ditunjukkan dengan pertumbuhan sebesar $29,6 \%$ pada jumlah SPT yang disampaikan secara elektronik, yaitu sebanyak 267.629 SPT atau 95.02\% dari 282.660 SPT yang dilaporkan se-Kanwil DJP Sumatera Utara II. Adapun KPP Pratama Pematang Siantar merupakan salah satu KPP dalam wilayah kerja Kanwil DJP Sumatera Utara II. Berdasarkan data yang diperoleh, berikut adalah data penggunaan e-system perpajakan dalam pelaporan SPT tahunan di KPP Pratama Pematang.

Tabel.1 Persentase Pelaporan SPT Tahunan KPP Pratama Pematang Siantar

\begin{tabular}{lcc}
\hline \multicolumn{3}{c}{ Persentase Pelaporan SPT Tahunan } \\
\hline Tahun & 2019 & 2020 \\
Total SPT yang masuk & 58.853 & 65.919 \\
Lapor Online & 56.497 & 51.634 \\
Persentase lapor online & $\mathbf{9 6 , 0 0 \%}$ & $\mathbf{7 8 , 3 0 \%}$ \\
\hline
\end{tabular}

Sumber: Seksi Pengolahan Data dan Informasi (PDI) KPP Pratama Pematang Siantar (2021)

Berdasarkan Tabel.1 terdapat penurunan penggunaan e-system perpajakan dalam pelaporan SPT tahunan tahun 2020 sebesar 17,7\% (96\%-78,3\%) jika dibandingkan tahun 2019. Pada pelaporan SPT tahunan 2020, KPP Pratama Pematang Siantar mencatat jumlah SPT yang disampaikan secara elektronik, yaitu sebanyak 51.634 SPT atau hanya 78,3\% dari 65.919 SPT yang dilaporkan. Persentase tersebut $17,0 \%$ berada di bawah persentase nasional dan $16,72 \%$ berada di bawah persentase akumulasi dari semua KPP yang berada di wilayah kerja Kanwil DJP Sumatera Utara II. Berdasarkan data tersebut, terdapat anomali penggunaan e-system perpajakan di KPP Pratama Pematang Siantar. Ditengah meningkatnya penggunaan layanan pelaporan SPT secara online baik secara nasional maupun lingkup kantor wilayah, namun KPP Pratama Pematang Siantar mencatat penurunan penggunaan pelaporan SPT Tahunan tahun 2020 secara online.

Permasalahan yang diangkat dalam tulisan ini ialah perbandingan penggunaan layanan e-system seperti e-registration, e-billing, dan e-filling dari tahun 2018 s.d 2020. Selain itu, permasalahan lainnya adalah hambatan yang dialami wajib pajak dan pegawai pajak dalam penggunaan layanan e-system. Sehingga diharapkan hasil penelitian ini dapat memberikan hipotesis guna optimalisasi penggunaan e-system perpajakan di KPP Pratama Pematang Siantar.

\section{LANDASAN TEORI}

\subsection{Kepatuhan}

Berdasarkan Kamus Besar Bahasa Indonesia, "patuh" memiliki makna taat pada aturan, pemerintah, dan sebagainya. Dengan demikian kepatuhan perpajakan memiliki arti ketaatan masyarakat dalam menjalankan aturan perpajakan yang ada di Indonesia. Sedangkan menurut Norman D. Nowak (n.d., dikutip dalam Rahayu, 2010) kepatuhan perpajakan tercermin ketika wajib pajak mengerti ketentuan peraturan perpajakan, menghitung dengan benar besarnya pajak, melengkapi formulir pajak dengan jelas dan lengkap, serta menyetorkan pajak tepat waktu.

\subsection{Kewajiban Perpajakan}

Sistem perpajakan Indonesia menerapkan self assessment system. Menurut Tiraada (2013) self assessment system mengharuskan wajib pajak untuk mendaftar, menghitung, membayar serta melaporkan sendiri jumlah pajak terutang yang menjadi kewajibannya. Wajib pajak dituntut berperan aktif untuk melaksanakan kewajiban perpajakannya 
sedangkan pegawai pajak (fiskus) sebagai pengawas (Ersania \& Merkusiwati, 2018) sehingga pelaksanaan pemenuhan kewajiban perpajakan memerlukan pemahaman wajib pajak terkait kewajiban perpajakannya.

Kewajiban mendaftarkan diri merupakan langkah awal yang dilakukan oleh wajib pajak. Setiap orang yang telah memenuhi persyaratan subjektif dan objektif diwajibkan untuk mendaftarkan diri dan memperoleh Nomor Pokok Wajib Pajak (NPWP).

Selanjutnya menghitung pajak secara mandiri. Untuk memenuhi kewajiban ini maka diperlukan pemahaman wajib pajak terkait dasar pengenaan Pajak Penghasilan (PPh) yang terkait dengan PPh final, penghasilan yang bukan merupakan objek pajak, penghasilan dari pemberi kerja, penggabungan penghasilan (suami-istri), hingga pengklasifikasian Penghasilan Tidak Kena Pajak. (Nugroho, 2009)

Pembayaran pajak ke kas negara merupakan kewajiban dari wajib pajak. Pembayaran pajak merupakan perwujudan dari kewajiban kenegaraan dan peran serta warga negara untuk secara langsung dan bersama-sama membiayai negara demi pembangunan nasional. (Edukasi Pajak, 2018)

Wajib pajak juga wajib melaporkan sendiri besarnya pajak yang harus dibayar menggunakan Surat Pemberitahuan (SPT) dan bertanggung jawab akan kebenarannya. (Supadmi, 2009)

\subsection{Layanan Pajak melalui E-System}

Penggunaan e-system dalam layanan DJP merupakan langkah simplifikasi pajak untuk meningkatkan kepatuhan wajib pajak dalam menjalankan kewajiban perpajakannya. Berikut ini adalah layanan e-system perpajakan DJP.

Layanan e-registration dapat diartikan sebagai sistem pendaftaran wajib pajak untuk memperoleh NPWP, perubahan data wajib pajak dan atau pengukuhan dan pencabutan pengukuhan pengusaha kena pajak secara online. Layanan pada sistem ini terdiri atas dua bagian, yaitu sistem online yang berfungsi sebagai media pendaftaran wajib pajak yang digunakan oleh wajib pajak, dan sistem online yang berfungsi sebagai media untuk memproses pendaftaran wajib pajak yang digunakan oleh pegawai pajak. (Ersania \& Merkusiwati, 2018)

Layanan e-billing merupakan salah satu menu yang terdapat pada djponline. Menurut Sulistyorini et al. (2017) e-billing system adalah sistem yang digunakan untuk membuat kode billing yang digunakan sebagai pembayaran atau penyetoran penerimaan negara secara elektronik, dengan mengisi surat setoran elektronik tanpa perlu membuat Surat Setoran Pajak (SSP) secara manual.

Layanan pelaporan SPT secara online adalah $e$ SPT, e-form dan e-Filling. Wajib pajak dapat menggunakan e-filling atau e-form di menu yang tersedia pada laman DJP online dan dapat dilakukan juga dengan menggunakan aplikasi $e$-SPT untuk merekam data perpajakan yang akan dilaporkan wajib pajak.

\subsection{Wajib Pajak dan Perpajakan Indonesia}

Adanya persepsi negatif pajak bagi wajib pajak masih sering ditemui karena pada prinsipnya, pajak merupakan beban bagi wajib pajak selaku pembayar pajak. (Simbolon, 2017) Perlu adanya perbaikan hubungan antara wajib pajak dengan otoritas pajak di Indonesia. Berdasarkan Darussallam et all. (2019), terdapat beberapa era baru hubungan Otoritas Pajak dengan wajib pajak diantaranya ialah:

Era baru melalui kepatuhan kooperatif, sebagai upaya untuk meningkatkan kepatuhan wajib pajak dengan mendorong tax morale (moral pajak) wajib pajak.

Era baru melalui simplifikasi, merupakan upaya untuk menurunkan kompleksitas sistem perpajakan. Dengan adanya simplifikasi sistem pajak maka akan menciptakan paradigma baru dalam meningkatkan kepatuhan wajib pajak. Namun upaya simplifikasi ini tetap memerlukan batasan-batasan agar tidak terjadinya distorsi.

Era baru melalui teknologi, upaya yang dilakukan untuk memanfaatkan teknologi dalam sistem perpajakan di Indonesia. Peran teknologi menjadi vital karena teknologi memungkinkan untuk wajib pajak menggunakan data dan informasi dalam memenuhi kewajiban perpajakannya dan pegawai pajak menjadi lebih transparan sehingga menciptakan basis kepercayaan antara wajib pajak dengan pegawai pajak.

\subsection{Teknologi dan Perpajakan Indonesia}

Pemanfaatan teknologi memberikan kemudahan dalam membantu proses administrasi pajak yang lebih sederhana. (Darussalam et al., 2019) Menurut Simbolon (2017), tujuan dari adanya sistem elektronik dalam perpajakan ialah sebagai salah satu wujud dari implementasi yang dilakukan untuk mencapai good governance di Indonesia. Hal itu tentu akan mempengaruhi pelayanan yang diberikan kepada wajib pajak, penegakan hukum perpajakan dan pemeriksaan pajak yang lebih efektif yang tentunya mempengaruhi tingkat kepatuhan dari wajib pajak (Simbolon, 2017). Tidak dapat dipungkiri keterlibatan teknologi telah mencakup keseluruhan dari kebutuhan wajib pajak dalam melakukan pemenuhan kewajiban perpajakannya.

\section{METODE PENELITIAN}

Pada penelitian ini, penulis menggunakan metode kualitatif. Raco (2010) menekankan metode kualitatif adalah mencari pengertian yang mendalam tentang suatu gejala, fakta atau realita. Gejala, fakta atau realita serta peristiwa hanya dapat dipahami bila peneliti menelusurinya secara mendalam dan tidak hanya terbatas pandangan di permukaan saja. Penelusuran secara mendalam ini yang menjadi ciri khas dari metode kualitatif, sekaligus faktor unggulannya. 
Dalam penelitian ini, sumber data dipeoleh dari arsip atau dokumen dan wawancara yang dilakukan terhadap 2 narasumber terkait. Arsip atau dokumen diperoleh langsung dari seksi PDI KPP Pratama Pematang Siantar dan situs internet terpercaya yang dapat diakses oleh masyarakat umum. Arsip atau dokumen yang dimaksud adalah data jumlah pengguna layanan e-registration, e-billing, dan e-filling perpajakan dari tahun 2018 s.d. 2020, data jumlah pengguna layanan e-system (e-filling) secara nasional, data jumlah penggunaan internet secara nasional dan lain-lain. Sedangkan narasumber dipilih oleh penulis berdasarkan pertimbangan kompetensi, pengetahuan, dan keahlian narasumber terkait topik penelitian ini. Narasumber yang dipilih merupakan pejabat di KPP Pratama Pematang Siantar meliputi:

1. Account Representative (AR) Seksi Pengawasan dan Konsultasi I

2. Pelaksana Seksi Pelayanan

Hasil wawancara oleh penulis dilakukan coding dengan memberikan label pada kata atau frasa yang mewakili tema penting di setiap tanggapan narasumber.

\section{HASIL PENELITIAN}

\subsection{Pelaksanaan Penggunaan E-System dalam Pemenuhan Kewajiban Perpajakan}

a) Kewajiban mendaftarkan diri

Dalam penerbitan NPWP, wajib pajak dapat memilih pembuatan NPWP dengan saluran online $(e-$ registration) atau manual (datang langsung ke KPP atau dengan mengirimkan formulir dan berkas yang disyaratkan melalui pos.

Berdasarkan data yang didapat dari KPP Pratama Pematang Siantar terjadi peningkatan penggunaan $e$ registration pada tahun 2018, 2019, dan 2020 dengan persentase masing-masing sebesar $12,0 \%$; $13,7 \%$; dan $75,7 \%$. Terjadi peningkatan yang signifikan pada tahun 2020. Hal ini didorong oleh situasi pandemi covid-19 yang menuntut adanya pembatasan sosial dan pengurangan layanan tatap muka di KPP Pratama Pematang Siantar.

\section{b) Kewajiban Membayar/Menyetor Pajak}

Sebelum melakukan pembayaran pajak, wajib pajak harus memiliki kode billing. Adapun cara yang dapat digunakan wajib pajak untuk memperoleh kode billing adalah melalui menu e-billing pada akun djponline ataupun cara lainnya seperti melalui teller bank atau pengiriman melalui pos, internet banking, kring pajak dan melalui tempat pelayanan terpadu (TPT) KPP Pratama Pematang Siantar.

Berdasarkan data yang diperoleh dari KPP Pratama Pematang Siantar, terjadi peningkatan penggunaan $e-$ billing pada tahun 2018; 2019; dan 2020 dengan persentase masing-masing sebesar 3,1\%; 3,2\%; dan $6 ; 1 \%$. Namun jika dilihat dari persentase saluran $e$ billing jumlanya tidak signifikan dibandingkan dengan saluran lainnya karena masih berada dalam rentang $3,1 \%-6,1 \%$. Hal ini terjadi karena ketidaktahuan wajib pajak dengan adanya layanan e-billing di menu djponline. c) Kewajiban Melaporkan SPT

Wajib pajak yang wajib melaporkan SPT Tahunan merupakan wajib pajak yang memiliki status NPWP efektif. Pelaporan SPT tahunan dapat dilakukan secara online dengan memilih menggunakan e-form, e-filling, atau $e$-SPT.

Berdasarkan data yang diperoleh dari KPP Pratama Pematang Siantar terjadi peningkatan pada tahun pajak 2019 namun terjadi penurunan pada tahun pajak 2020 dengan persentase 2018;2019; dan 2020 masing-masing $86,5 \% ; 96,0 \%$; dan $78,3 \%$. Terjadinya penurunan pada tahun pajak 2020 disebabkan tingkat pemahaman dari wajib pajak yang masih kurang dan adanya miskomunikasi antara wajib pajak dengan pegawai pajak. Miskomunikasi yang dimaksud adalah anggapan wajib pajak bahwa tidak timbulnya kewajiban perpajakan di masa pandemi covid-19 dan anggapan kegiatan melaporkan SPT merupakan tugas dari bendahara atau operator kantor tempat wajib pajak bekerja.

\subsection{Hambatan-Hambatan Penggunaan E-system}

a) Hambatan Wajib Pajak

Wajib pajak sebagai user memiliki hambatan seperti kurangnya pemahaman wajib pajak terkait $e$ system DJP dan adanya anggapan bahwa kantor pajak masih sepenuhnya menggunakan cara manual, sosialisasi yang kurang intens dari kantor pajak dalam penggunaan layanan online kepada setiap wajib pajaknya, informasi atau pengumuman yang disampaikan kantor pajak tidak secara utuh diterima wajib pajak sehingga menyebabkan terjadinya miskomunikasi atau anggapan bahwa pada tahun 2020 tidak timbul kewajiban perpajakan.

Selanjutnya hambatan yang sering dialami adalah dari sisi teknis seperti seringnya system error di saat mendekati jatuh tempo dan ketidaktersediaan perangkat (device) seperti handphone maupun laptop wajib pajak bersangkutan.

b) Hambatan Pegawai Pajak

Pegawai pajak sebagai pengguna sekaligus penyuluh penggunaan layanan e-system juga memiliki hambatan diantaranya ketidakefektifan beberapa kunjungan dan sosialisasi langsung di lapangan, disebabkan proses vaksinasi covid-19 yang sedang berlangsung. Kurang efektifnya beberapa pekerjaan akibat adanya wajib pajak yang tidak paham teknologi dan tingkat kemauan belajar yang rendah. Contohnya pegawai yang masih melakukan pendaftaran akun $e$ mail dari wajib pajak. Hal tersebut tentu menyita banyak waktu pegawai pajak.

Selanjutnya hambatan yang sering dialami adalah sistem layanan online pajak yang mengalami error saat mendekati jatuh tempo sehingga pegawai harus melakukan jam lembur (extra time).

\subsection{Solusi yang Dilakukan}

Berikut ini adalah solusi yang telah dilakukan oleh KPP Pratama Pematang Siantar untuk menghadapi hambatan-hambatan yang dialami wajib pajak maupun pegawai pajak yaitu dengan melakukan penyuluhan 
secara online maupun kunjungan langsung dengan memperbanyak kelas pajak baik secara online (dengan memberikan video tutorial) ataupun kunjungan langsung ke instansi dan lembaga wajib pajak terkait. Menyediakan layanan mandiri berupa komputer, printer hingga jaringan internet yang bebas digunakan setiap wajib pajak untuk menunaikan kewajiban perpajakannya di areal kantor. Pegawai juga mengarahkan wajib pajak untuk menggunakan sistem online secara mandiri, sehingga wajib pajak mendapat pengalaman dan mulai terbiasa menggunakan menu yang tersedia. Kemudian melakukan kampanye "lebih awal lebih nyaman" untuk mencegah membludaknya penggunaan layanan e-system perpajakan mendekati tanggal jatuh tempo.

\subsection{Upaya Optimalisasi Layanan melalui E-System}

Upaya optimalisasi perlu dilakukan untuk meningkatkan penggunaan e-system. Tingkat pemahaman, literasi perpajakan, hingga kurangnya pengetahuan e-system perpajakan menjadi penghambat terbesar. Berdasarkan penelitian yang dilakukan Widayati \& Nurlis (2010) faktor pengetahuan dan pemahaman perpajakan memiliki pengaruh yang signifikan terhadap kemauan wajib pajak memenuhi kewajiban perpajakannya sedangkan persepsi yang baik atas efektivitas sistem perpajakan mempunyai pengaruh yang tidak signifikan. Jika diperhatikan dari solusi yang telah dilakukan KPP Pratama Pematang Siantar, sosialisasi yang diberikan kepada wajib pajak lebih mengarah kepada teknis-teknis perpajakan. Wajib pajak lebih sering disuguhkan dengan teknis dan tata cara perpajakan daripada meningkatkan kepatuhan perpajakan dengan mendorong moral pajak (tax morale). Hal tersebut menyebabkan kepatuhan sukarela dan antusias penggunaan e-system masih kurang.

Meningkatkan literasi perpajakan setiap wajib pajak merupakan langkah awal yang dapat dilakukan. Merubah pandangan wajib pajak dengan pendekatan persuasif bahwa kedudukan wajib pajak bukan hanya pembayar pajak, namun juga penikmat pajak melalui program-program pemerintah. Perlakuan maupun pelayanan yang diberikan pegawai pajak juga mempengaruhi kemauan wajib pajak untuk patuh, karena psikologi dan sosiologi juga turut dapat membantu proses pengambilan keputusan dari wajib pajak untuk memenuhi kewajiban perpajakannya dan meningkatkan antusias wajib pajak menggunakan $e$ system perpajakan.

\section{KESIMPULAN DAN SARAN}

\subsection{Kesimpulan}

Berikut ini adalah kesimpulan yang dapat diambil berdasarkan hasil pembahasan sebelumnya terkait pelaksanaan penggunaan e-system, hambatan yang dialami wajib pajak dan pegawai pajak hingga upaya optimalisasi penggunaan e-system perpajakan yang dapat dilakukan.

Pelaksanaan penggunaan e-system dalam pemenuhan kewajiban perpajakan di KPP Pratama Pematang Siantar dilihat dari penggunaan $e$ registration, e-billing, e-filling, e-form, dan e-SPT.
Terjadi peningkatan penggunaan e-registration dan $e$ billing dari tahun 2018 s.d. 2020. Peningkatan yang cukup signifikan terjadi pada penggunaan e-registration pada tahun 2019 s.d. 2020 dengan peningkatan 62,0\%. Sedangkan untuk penggunaan e-billing walaupun terjadi peningkatan setiap tahunnya secara persentase masih sangat rendah yakni hanya berada dikisaran 3,1\%-6,1\% dari total pembuatan kode billing. Untuk pelaporan SPT tahunan secara online juga masih belum optimal, terjadi penurunan dari tahun 2019 s.d. 2020 dimana terjadi penurunan sebesar $18,9 \%$.

Hambatan-hambatan wajib pajak dalam menggunakan layanan pajak berbasis e-system berasal dari faktor internal dan eksternal. Faktor internal yang dimaksud diantaranya adalah kurangnya pemahaman terkait layanan pajak berbasis e-system, ketidaklengkapan perangkat yang dimiliki hingga kurangnya literasi perpajakan dari wajib pajak. Sedangkan faktor eksternal yang dimaksud adalah faktor yang berasal dari sisi Direktorat Jenderal Pajak. Menurut wajib pajak sosialisasi perpajakan masih kurang intens, adanya Informasi atau pengumuman yang tidak sampai ke wajib pajak hingga sistem online yang disediakan sering terjadi error. Adapun hambatanhambatan yang dialami pegawai berasal dari faktor internal dan eksternal. Faktor internal adalah tingkat pemahaman dari setiap pegawai pajak yang berbedabeda dimana tidak semua pegawai mengetahui info terbaru (update) dari layanan e-system ini. Sistem online Direktorat Jenderal Pajak yang masih belum mumpuni untuk menampung seluruh akses wajib pajak juga menjadi penghambat bagi pegawai. Sedangkan faktor eksternal yang dimaksud diantaranya adalah kegiatan vaksinasi covid-19 yang mengakibatkan tidak efektifnya beberapa kunjungan dan sosialisasi di lapangan, kesulitan menjangkau wajib pajak yang berada di daerah-daerah, hingga menghadapi wajib pajak yang tingkat kemauan belajar dan pemahaman perpajakan yang rendah.

Meningkatkan literasi perpajakan wajib pajak adalah langkah awal yang paling tepat untuk memasyarakatkan pajak. Adanya hubungan yang baik antara wajib pajak dengan pegawai pajak juga memiliki peranan yang penting agar wajib pajak merasa nyaman dan tidak dipersulit sehingga pandangan negatif wajib pajak terhadap perpajakan juga dapat dihilangkan. Hal ini disebabkan karena secara psikologis antusias wajib pajak meningkat dan pemanfaatan e-system perpajakan dapat lebih optimal dimanfaatkan wajib pajak di KPP Pratama Pematang Siantar.

\subsection{Saran}

Berikut ini adalah saran yang dapat diberikan penulis kepada wajib pajak, KPP Pratama Pematang Siantar, dan Direktorat Jenderal Pajak. Wajib pajak sebaiknya mulai meningkatkan literasi perpajakannya secara mandiri dan aktif mencari informasi perpajakan dari sumber-sumber terpercaya. Kemudian KPP Pratama Pematang Siantar perlu melakukan sosialisasi dengan pendekatan persuasif sehingga persepsi negatif 
pajak bagi wajib pajak dapat dihilangkan secara bertahap. Selanjutnya untuk Direktorat Jenderal pajak, perlu meningkatkan kualitas dan kapasitas layanan online DJP dan melakukan stress test pada sistem sehingga kedepannya error atau server down dapat dihindari.

\section{IMPLIKASI DAN KETERBATASAN}

Hasil penelitian ini berimplikasi terhadap praktik penggunaan layanan e-system di KPP Pratama. Penelitian ini memiliki keterbatasan dan tidak sempurna baik dari segi ketersediaan literatur dan pengetahuan penulis. Penelitian ini diharapkan dapat menjadi pertimbangan bagi KPP Pratama dalam optimalisasi penggunaan layanan e-system dalam pemenuhan kewajiban wajib pajak.

\section{DAFTAR PUSTAKA (REFERENCES)}

Asmarani, Nora Galuh Candra. 2020. Mau Lapor SPT Pakai E-Filling atau E-Form? Cek Bedanya di Sini. Diakses pada 17 Februari 2021 dari, https://news.ddtc.co.id/mau-lapor-spt-pakai-efiling-atau-e-form-cek-bedanya-di-sini/

Bauti, Y. S. (2018). Analisis Perbandingan Sistem Manual dan Elektronik pada Pelaporan SPT Tahunan di Kpp Pratama Jakarta Setiabudi Empat.

Clarymond Simbolon. (2017). Tinjauan Manfaat Modernisasi Administrasi Perpajakan melalui Pengembangan Teknologi Aplikasi Terhadap Kemudahan Wajib Pajak dan Kinerja Direktorat Jenderal Pajak.

Darussalam, Septriadi, D., Kristiaji, B. B., \& Vissaro, D. (2019). Era Baru Hubungan Otoritas Pajak dengan Wajib Pajak.

Direktorat Jenderal Pajak. (2018). Prosedur Pemenuhan Kewajiban Perpajakan1.Diakses pada 21 Maret 2021 dari,

https://www.pajak.go.id/sites/default/files/201903/KUP-02 DHBL Rev.1.pdf.

Direktorat Jenderal Pajak. (2021). April 2021, Jumlah Pelaporan SPT Tahunan Sumut II Meningkat. Diakses pada $6 \quad$ Mei 2021 dari, https://www.pajak.go.id/index.php/id/siaranpers/april-2021-jumlahpelaporan-spt-tahunansumut-ii-meningkat.

Ersania, G. A. R., \& Merkusiwati, N. K. L. A. (2018). Pengaruh Penerapan E-system Perpajakan Terhadap Tingkat Kepatuhan Wajib Pajak Orang Pribadi. EJurnal Akuntansi

Hakim, M. M. (2016). Analisis Model Penerimaan Pengguna Sistem Pelaporan Pajak Online.

Hardiningsih, P. (2011). Faktor-Faktor yang Mempengaruhi Kemauan Membayar Pajak.

Irawan, A. W., Yusufianto, A., Agustina, D., \& Dean, R. (2020). Laporan Survei Internet APJII 2019-2020 (Q2).

Jawas, F., Diatmika, P. G., \& Yasa, N. P. (2017). Efektivitas Penerapan Sistem Elektronik Dan Pelayanan Perpajakan Terhadap Penerimaan Pajak (Studi Kasus Pada Kantor Pelayanan Pajak Pratama Singaraja, Bali). JIMAT (Jurnal IImiah Mahasiswa Akuntansi S1)

Murry, M. S., Ni Kadek Sinarwati, \& Gede Adi Yuniarta.
(2017). Persepsi Fiskus dan Wajib Pajak Orang Pribadi (WPOP) terhadap Penerapan E-Billing pada Kantor Pelayanan Pajak (KPP) Pratama Singaraja. EJournal S1 Ak Universitas Pendidikan Ganesha

Nugroho, S. D. A. (2009). Cara Mudah Menghitung Pajak Pribadi.

Pujiani, M., \& Rizal, E. (2014). Analisis Efektivitas Penggunaan E-system Terhadap Penerimaan Pajak di KPP Pratama Palembang Illir Timur.

Raco, J.R. (2010). Metode Penelitian Kualitatif Jenis, Karakter, dan Keunggulannya. Jakarta: PT Grasindo

Siti Kurnia Rahayu, 2010. PERPAJAKAN INDONESIA: Konsep dan Aspek Formal, Yogyakarta: Graha IImu.

Romi, K. (2017). Strategi Komunikasi Kantor Pelayanan Pajak Pratama Pekanbaru Tampan dalam Meningkatkan Kesadaran Wajib Pajak di Pekanbaru melalui Sistem Layanan Pajak Online E-Billing.

Rysaka, N. (2014). Penerapan Sistem Elektronik Dalam Pelayanan Perpajakan (Studi Pada Kantor Pelayanan Pajak Pratama Malang Utara). Jurnal Administrasi Publik Mahasiswa Universitas Brawijaya

Sukiyaningsih, T. W. (2020). Studi Penerapan E-System Dan Pelaksanaan Self Assesment System Terhadap Kepatuhan Wajib Pajak.

Sulistyorini, M., Nurlaela, S., \& Chomsatu S, Y. (2017). Pengaruh Penggunaan Sistem Administrasi ERegistration, E-Billing, E-SPT, Dan E-Filling Terhadap Kepatuhan Wajib Pajak (Studi Pada Wajib Pajak Orang Pribadi Di RSUD Dr. Moewardi Surakarta). Jurnal Ekonomi Universitas Islam Batik

Supadmi, N. (2009). Meningkatkan Kepatuhan Wajib Pajak Melalui Kualitas Pelayanan. Jurnal IImiah Akuntansi Dan Bisnis

Tiraada, T. A. M. (2013). Kesadaran Perpajakan, Sanksi Pajak, Sikap Fiskus terhadap Kepatuhan WPOP di Kabupaten Minahasa Selatan

Tobing, G. C. (2019). Akankah Taxologist menjadi Profesi Baru di Era Pajak 4.0?

Widayati, \& Nurlis. (2010). Faktor-Faktor yang Mempengaruhi Kemauan Membayar Pajak Wajib Pajak Orang Pribadi yang Melakukan Pekerjaan Bebas.

Widjaja, H., \& Siagian, A. J. S. J. (2017). Analisis Penerapan E-System Perpajakan pada Wajib Pajak Pribadi terhadap Pelaksanaan Self-Assesment System dalam Memenuhi Kewajiban Perpajakan. Jurnal Ekonomi 